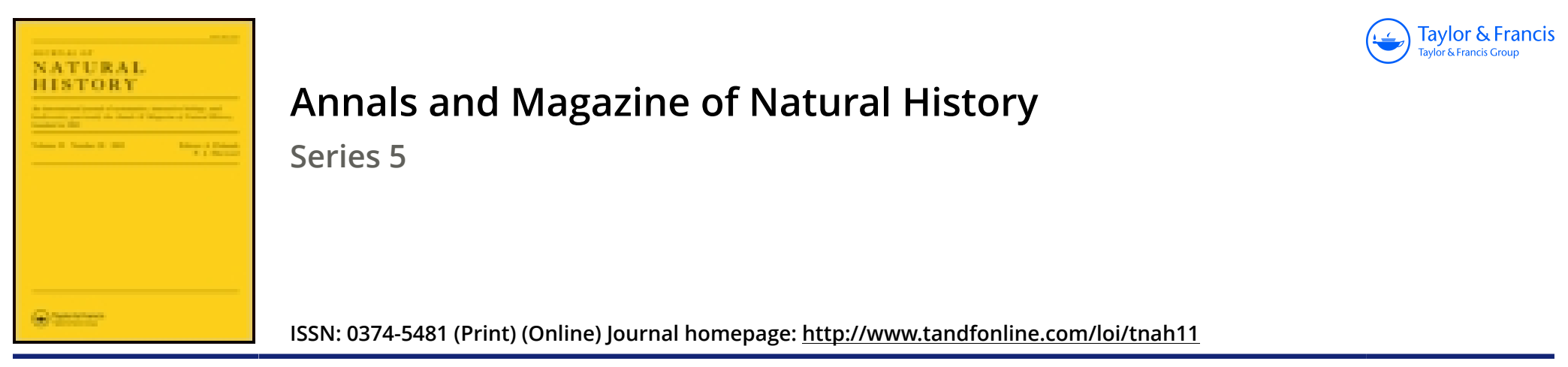

\title{
XXX.-On the kunker formation of the alluvium in India compared with the flint formation in the chalk of England
}

\section{H.J. Carter F.R.S.}

To cite this article: H.J. Carter F.R.S. (1881) XXX.-On the kunker formation of the alluvium in India compared with the flint formation in the chalk of England, Annals and Magazine of Natural History, 7:40, 308-312, DOI: 10.1080/00222938109459518

To link to this article: http://dx.doi.org/10.1080/00222938109459518

曲 Published online: 07 Oct 2009.

Submit your article to this journal

ЏII Article views: 3

Q View related articles $₫$ 
then known, says "Scutellum nullum ;" but in characterizing the genus he rightly says "Scutellum minutum, punctiforme."

\section{Ithaura nitida.}

I. oblongo-elliptica, vix depressa, silaceo-brunnea, nitida; rostro cum capite inter oculos carinato et rude punctato. Long. $3 \frac{1}{2}$ lin.

Hab. Parana.

Oblong elliptic, scarcely depressed, glossy yellowish brown; rostrum shorter than the prothorax, a central carina at its base, commencing between the eyes, with three rows of coarse punctures on each side; antennæ short and stout, slightly pubescent; prothorax longer than broad, abruptly constricted at the apex, remotely and rather finely punctured; scutellum small, somewhat transverse, rounded; elytra delicately striate, the striæ marked with coarse oblong punctures, the alternate interstices raised posteriorly; tibiæ short, seriately setulose; tarsi very small.

The type species of this genus is figured and described in the 'Journal of the Linnean Society,' vol. xi. pl. vi. fig. 2, pp. 215, 216. It is a longer and proportionally narrower insect than this species, differently sculptured, and with a rather dull varnished appearance. The genus is allied to Aphyoda, another singular form, and both approximating to the group of which our too well-known Calandra granaria is an example; but the head deeply constricted behind the eyes, and the small portion which lies between them, seem alone to warrant their separation as a group apart.

Of some of the species described in these papers coloured figures will be given in Mr. C. Waterhouse's 'Aid to the Identification of Insects.'

XXX.-On the Kunker Formation of the Alluvium in India compared with the Flint Formation in the Chalk of England. By H. J. Carter, F.R.S. \&c.

Perhaps De la Beche and Elie de Beaumont were the first to insist more especially on the necessity of studying the present to interpret the past in geology-thus avoiding all theory and speculation in establishing facts which, if pursued truthfully, offer great attraction to the scientific mind, but, if otherwise, cannot fail to do the opposite.

Under such views I venture to compare the formation of the nodular and so-called "sheet" kunker of India with 
that of flints and chert in the Upper Chalk and Greensand of England respectively-bearing in mind that the former is in alluvial deposits and calcareous, and that the latter are parts of the Cretaceous system and siliceous.

Among the "Post-tertiary and Recent Formations" of India mentioned in Medlicott and Blanford's 'Manual of the Geology of India,' 1879 (vol. i. p. 371), it is stated :- that kunker is "concretionary carbonate of lime," most commonly presenting itself " in nodules of an irregular shape from half an inch to three or four inches in diameter," as well as in "thick beds, in the alluvium," ... " often filling cracks in the latter and the older rocks" beneath (p. 381); that " at Bombay the alluvial deposits consist of blue and yellowishbrown clay," of which the former " contains small grains and nodules of kunker," while the latter " abounds with it in large masses" (p. 424); and, lastly, that the regur, or black soil of India generally, which is argillaceous, usually, when more than about 6 to 10 feet deep, passing downwards into brown clay, also "abounds in kunker" (p. 431).

The late Captain Newbold observes of the regur, that " from Courtney to Yailbenchi, four miles, the plain continues as before, covered with a substratum of regur, or black cotton-soil of India, to a depth of 1 to 18 feet, in many places resting immediately on gneiss and granite, in others on an intervening bed of calcareous deposit somewhat resembling the travertin of Italy, though more nodular, and called by the natives 'kunker.' It is burnt by them for lime. Like rows of flints in chalk it is seen also in the lower layers of the regur often with sharp projecting spiculæ of carbonate of lime, which would have been broken off had the nodules been drift-pebbles." ("Notes, principally Geological, on the Tract between Bellary and Bijapore,' by Captain Newbold, F.R.S. \&c., Madras Army. Reprinted in Carter's 'Geological Papers on Western India,' 1857, p. 308.)

In the same compilation, under the head of "Kunker," in the index (p. 780), will be found references to all that had been stated of kunker up to that time, viz. 1857 ; while at pp. 159 and 700 are my own accounts respectively of the kunker formation as it occurs at Bombay and over India generally. They are as follows:- "There is a feature of this clay ('Geology of the Island of Bombay,' 1850), however, which is very remarkable, viz. the kunker formation. This, which consists of concretionary limestone, occurs massive or scattered throughout the clay in small isolated portions. In its massive state it is found in large boulders or in continuous tracts, reposing on the freshwater strata or igneous rocks 
beneath, and in this state is compact and cavernous, enclosing portions of the clay in its cavities \&c. in which it has been formed; or as a conglomerate with sandy or gravelly detritus from the igneous rocks, and the remains of small shells, assimilating it to the sandy beaches [littoral concrete]. Those portions which are scattered throughout the clay are more or less round, like Septaria; very uniform in structure, and some so pure that they wholly dissolve in nitric acid. They are generally of a blue colour, but sometimes quite white and identical with chalk. Like Septaria, also, they are irregular and almost invariably envelope the remains of some organic matter, such as pieces of reed, wood, the remnants of crabshells, \&c., which are very frequently removed, and leave nothing but their moulds in the centre of the concretions. This substance also accumulates in the interior of shells and almost always fills the cavities of pholadine tubes which have been formed in the clay. It does not always, however, envelope organic remains, but may be seen appended to them in a globular form-to the pincher of a crab-claw, for instance. Occasionally it may be seen, in a vertical section of the clay, in the state of a number of isolated particles or concretionary nuclei round a piece of wood, as if in process of forming a nodule, not by successive layers, but by the increase of substance round different centres."

As much the same statement is given in my 'Summary of the Geology of India' (1858), I need not repeat it here, nor add more than that the surface of the regur generally is overspread with the nodules of kunker which have been weathered out of it, and that, in a great many parts of the Southern Mahratta country (according to Lieut. Aytoun, Geol. Papers, op. cit. p. 389), it occurs continuously at the bottom of the regur, in the form of a conglomerate, which he terms "sheet kunker."

Although remnants of organic matter in the kunker do not appear to have become fossilized generally, yet Captain W. T. Nicholls, formerly of the 24th Regiment, Madras Native Infantry, who was a very good and accurate observer, states with reference to some on the black soil, which he discovered in Central India near Narrainpoor, about 17 miles south-east of Saugor, as follows, viz. :-" I found fossils in three spots on the surface of the regur soil. At the first spot, fragments of dicotyledonous wood with a fragment of palm, one fragment of fossil bone, and a fossil ? palm-seed, converted into tuffaceous lime [kunker]. At the second spot, fragments of large bones strewed on the surface of the black regur soil, aind one or two fragments of fossil wood, together with irregular 
flat pieces of tuffaceous limestone loose on the surface. These bones are silicified." . . . "The third spot is about 150 yards from the last; and here I found dicotyledonous wood only. ... They lie on the black regur soil; and I see nowhere else that they could have come from but out of it" (Geol. Papers, op. cit. p. 766). It would therefore appear that, in some parts, the organic remains of the regur have become transformed into kunker, which, under the circumstances, does not appear extraordinary.

Thus we have the kunker lying in loose nodules on the surface, occurring in seams like flints; appended to or enclosing organic remains, or in the form of layers embodying heterogeneous material; sometimes transforming the organic remains of the regur into its own substance. Hence, if we were to substitute the terms "flint" and "chert" for the nodular and so-called "sheet" kunker, the description would apply equally well, mutatis mutandis, to the Upper. Chalk and Greensand.

Now, as regards the flints and chert, I happen to be living on the New Red Sandstone (at Budleigh-Salterton, Devon) where the surface is covered generally with the silicified débris of the Upper Chalk and Greensand which once overlay it in their integrity; and I observe that, together with other fossils, there are a great number of sponges, especially belonging to the Lithistina (Prof. Zittel's "Megamorina" and "Tetracladina"). Taking one of these I find :-1st, that a flint may be appended to it; 2 ndly, that the fint may enclose it; 3rdly, that the flint may have so extended into it as to obliterate all trace of the structure of the Lithistid; 4 thly, that a mould only of the Lithistid structure may remain in the intruding flint; further, that in most cases the flint is homogeneous and nodular, while, on the other hand, the fragments of chert are heterogeneously composed and tabular-indicating that the former was more exclusively concretionary than the latter. On the surface of some enclosed specimens of Lithistina that I have knocked out from flint, the stelliform discoid stage in the development of the lithistid spicule remains on the surface, showing that nothing more than the thin, circular, discoid one had disappeared, which is a common occurrence even among recent specimens.

Apart, however, from the siliceous material which we call "flint," there may be a simple silicification of a calcareous shell, which would be a facsimile of the original form. Or, as I have shown in the sponge-spicules from the Carboniferous Limestone near Glasgow in Scotland, and Sligo in Ireland, respectively, the original material of the organic remains may 
undergo more than one change: thus as these spicules are now composed of chalcedony and yet present the rhombohedral excavations of calcite on their surface, they must previously have been carbonate of lime; and we know from their forms that they were originally siliceous spicules.

Under what circumstances these alterations take place, or how they may occur, or why the mineral should be changed, must be a matter of conjecture; but that they do occur we have evidence in the case just mentioned and in the formation of all mineral pseudomorphs; so that, if the mould of a Lithistid in flint, such as I have mentioned, were filled up with calcite and the flint subsequently removed, the original structure, instead of being siliceous, would be calcareous, or it might be pyritic, and so on. In two parcels of powder which came from the interior of two separate flints from Wallingford, Berkshire, the Coccoliths, which abound in both, are all silicified in one, and all calcareous in the other.

Where the siliceous material of which the flints and chert are composed came from I do not pretend to say, any more than the calcareous material which formed the kunker, especially the latter, seeing that out of eight analyses the quantity of lime only amounts to a mean of about nine parts in a thousand taken from the regur in eight different places, the lowest quantity of which, in three of the instances, did not reach two parts (Medlicott and Blanford, op. cit. vol. i. p. 430).

It may, however, be fairly inferred that the purer material will be found in the nodular forms, both of flint and kunker, and the less pure in the tabular forms, viz. the sheet kunker and the chert respectively.

Thus have I endeavoured to correlate that which may be said to be going on at the present day with what has taken place in ages past-not that such concretionary formations are confined to kunker and flint, for all geologists know that such have been taking place in the stratified deposits from the beginning; but to comprehend all, so far as we are able, is best accomplished by studying what is taking place at the present moment for comparison with what has taken place heretofore, since this kind of induction is the least exposed to error.

XXXI.-General Considerations upon the Carcinological Fauna of great Depths in the Caribbean Sea and Gulf of Mexico. By Alphonse Milne-Edwards*.

The progress which submarine investigations have caused

* Translated from the 'Comptes Rendus,' February 21, 1881. 